\title{
Educational spaces and environments: in times of Covid- 19 pandemic
}

\begin{abstract}
The appearance of COVID-19 brought to Brazil, and to the world, innumerable methods to contain the increase of infected people. These methods are necessary to avoid the spread of the virus and include social distancing and quarantine of the population. Knowing that these methods have a big impact on the educational system. This study has as its objective to verify the process of teaching and learning, in educational spaces and environments, in times of a pandemic. In order to look for a pattern in established actions in educational programs to incorporate in large scale the tools of educational technology at a distance (distance learning), for example platforms and virtual teaching environments designed to guarantee the pedagogical processes of learning and ameliorate the impact of absence from the classroom during the pandemic, and its post-pandemic consequences. We emphasize the importance of the teacher as mediator, understanding that this professional should respect the different levels of learning of the students and try to carry out activities that help with the improvement of practical education for the appropriate environment and spaces of interaction.
\end{abstract}

Keywords: educational environments, educational technologies, pandemic Covid-19 distance learning, educational spaces - learning

\author{
Volume 5 Issue 6 - 202I
}

\author{
Jailma Cruz da Silva,' Orliel dos Santos de \\ Jesus $^{2}$ \\ 'Specialist in NPGA/UFBA Innovation Planning and Management, \\ Master in Interdisciplinary Studies at the EISU/IHAC University \\ of UFBA, Brazil \\ 2Bachelor's Degree in Library Science and Documentation from \\ the Federal University of Bahia - UFBA, Degree in Pedagogy \\ from the State University of Bahia - UNEB, Specialization \\ in Higher Education Methodology by Fundação Visconde de \\ Cairu- (Salvador-Ba), Specialization in Institutional and Clinical \\ Psychopedagogy from the Faculty of Sciences of Baiana - \\ FACIBA, Brazil
}

Correspondence: Jailma Cruz da Silva, Specialist in NPGA/ UFBA Innovation Planning and Management, Master in Interdisciplinary Studies at the EISU/IHAC University of UFBA, Feira de Santana/Ba/Brazil, Brazil, Email yllmac@gmail.com

Received: November 16, 2021 | Published: November 24, 2021

\section{Introduction}

The educational system has not satisfactorily responded in a way that meets the needs of students and social demands. Nowadays, a new identity is fostered in the teaching practice, aiming at the formation of a professional who pays attention to the insertion of students in the process of integral, conscious and reflective citizens. Therefore, this work proposes to observe, theoretically, the teaching and learning process, in educational spaces and environments, in the pandemic context by Covid-19, based on the understanding that new educational technologies will provide opportunities for the application of obtained theories in the course of professional training, for a reflection on the reality in the classroom, in other words, the pedagogical practice focused "for whom" and "for what", enabling a pedagogical posture that favors creation and transformation.

\section{Educational spaces and environments: definition}

The concept of educational space and environments has gained new connotations, which expand its possibilities, no longer merely representing the decoding of what is written. Space, according to Brasil" "its components are articulated with the political-pedagogical project, which contribute to achieving educational goals". On the other hand, educational environment according to Sandrini (2015) is understood as a set of people, physical structures, norms, laws, ways of doing that affect the lives of everyone who participates in the educational community. It is a fact that the true space and environment is one that goes beyond decoding, as the discovery and implementation of technologies occurs continuously, which leads to reflection and analysis, as it allows for broadening horizons, leading teachers and students to discover new worlds. For Brasil" "objective, measurable material space, but it only becomes space for me, for educators in a school, for students, as the senses - especially the vision - capture the material elements that compose it", that is, even if it is a physical structure, but it needs to have a significance so that it provides learning.

Therefore, with a focus on the integral development of students, making the best use of spaces, Brasil ${ }^{1}$ comments that:

Hence an essential consequence for all educators, especially for school space managers: we can create space, we can change spaces, we can adapt spaces to educational goals. In this way, it is understood that an educational space is, in general, every place where the education of human beings is developed. The example, the family which establishes the first educational space where each individual is inserted, this being the environment in which he will be made aware of his primary role and where the socialization process begins, which will lead to articulation with the community. Another educational space is the school where you will have collaborative experiences and a notion of systematized education with established standards.

\section{Learning spaces technology: virtual and physical}

Learning cannot be understood as acquired in a natural way, and therefore, it requires space for its development, in this way, several social environments can be demanded in the educational and technological formation process, among them, the family and the school are the main agents disseminators of this tool. The spaces are classified as physical and virtual, which in the context of technology education assume different environments despite similar resources. Lévy $^{2}$ makes considerations about virtual realities, noting that they increasingly serve as communication media. In this sense, Schnitman ${ }^{3}$ states that: "an important prerequisite for the teacher to leverage this change in attitude translates into awareness of this new territoriality, located in the virtual environment", thus it is increasingly There is an evident awareness that having knowledge and exploring the 
boundaries and probabilities of the learning environments announced by $\mathrm{EAD}$ is a relevant starting point for reflecting on the didactic dynamics in this new innovative context.

It is important to highlight that the teacher mediator of the virtual environment must interact and have knowledge of different types of technological interfaces that virtual environments offer, always with a view to the issue of pedagogical mediation, which can be favored in this context. Thus, according to Ramal ${ }^{4}$ the "teaching and learning in Virtual Learning Environments (AVA), opportunities for interaction, information channels and quick feedback", between the student and the mediator teacher. For Moraes: ${ }^{5}$ Once introducing an object - the computer -, our relationships started to happen also in an environment called cyberspace through e-mails, chats, cyberconferences, cybercafés, etc. which, like the telephone, fax and other means, allow and mediate contact between two or more human beings, enabling symbolic exchanges between them. Faria ${ }^{6}$ warns about the fact that the mediator teacher interferes in the interactivity of the Virtual Learning Environment - AVA, highlighting that:

Often, what makes interactivity in virtual environments more difficult is the teacher himself. To the extent that the teacher is not fully aware of how interactive he should be in order to stimulate/ motivate his students to be more and more interactive, the process tends to slow down, cooling down. ${ }^{6}$ Physical space is defined as the place where something or something is inserted. And Freyberger ${ }^{7}$ believes that:

Space is physical and material, however, it does not exist without its cultural, historical and social dimensions. Doors, windows and floors, houses, streets and cities, all theoretically configure a space, but it is people, objects, colors, textures, smells and sounds that qualify it as an environment. From the object to the urban landscape - perception, culture, and customs are decisive in the spatial configuration, characterizing the activities and social relations that are established there. Man, by making use of this space, transforms it into an environment.

In this context of physical space, we highlight the school as the main vehicle for technological inclusion, however we must consider the other training agents that directly influence this audience. The school space is a complement to the mediation of knowledge and technological training, its role according to Brazil ${ }^{1}$ is defined as:

The school space is, at the same time, the set of materialities that make up the various environments frequented by educators and students and the "felt space", the space of awareness where teaching and learning activities take place. In this context, Fornero ${ }^{8}$ comments that even differentiating space and environment, he recognizes that they are closely linked, making it possible to understand space with a broader perspective. Thus, two agents will be listed in the following sessions, according to the objective to be achieved in the teachinglearning process of this student in Brazilian public education: family and school.

\section{Family}

The formation of subjects is based on the action of the family, which favors their improvement at school, opening up possibilities for an infinite universe of knowledge. In most cases, it is within the family that the subject has the first contact with world technology, such as: TV, radio, computer, cell phone, etc. Parents and children can share pleasant experiences through the technological world, with the various benefits whether in leisure or education. Silva ${ }^{9}$ tells us that "children learn from the moment they come into the world. She learns by listening to her mother's conversations inside and outside the house". Through family dialogue, parents prepare their children to face the world. The act of learning is important, as it will only be really valid if it makes sense to the learner. She always learns with the aim of making sense of things and especially when she has something or someone that serves as an example.

It is common for a father who works for example a carpenter, wants to teach his son the trade and from an early age the child starts to observe and over time the father gives him a chance to have contact with the raw material. These contacts arouse a taste for the profession. Even if you don't do it later, you will know how important it is.

In other words, if the child learns and situates himself in the world through the attribution of meanings and situations present in his family environment, then we can clearly infer that this environment is potentially significant. For Silva "it depends fundamentally on the incitements of the socio-cultural environment, that is, on the quantity and quality of stimuli found in the environment where the child lives and on the relationships he or she establishes with these stimuli".

It is important to emphasize that technological training is not entirely attributed to the school. The school would complement what the child learns within the family in an innovative way, that is, it uses educational technological resources. Through teaching, the school is responsible for providing conditions for students to know or recreate existing knowledge in different areas, through research the school takes on the challenge of creating knowledge that the student does not yet have. Despite the government's commitment to the development of educational policies, their assistencialist tendency is noticeable instead of seeking to resolve the primordial issues of Brazilian education, an example of which is educational technological resources, most of the time, it is inserted in schools without support or qualified professionals suitability and use.

They do not work in every school nucleus, as the vast majority of public schools, in which physical conditions are precarious, the teaching staff lack qualified professional training, poorly paid, without stimuli. So, covertly, when faced with problems in the classroom, some play that they teach and others play that they learn. Here is the fulfillment of some invisible goals of the government proposals. However, it is not possible to discuss whose fault it is, it is time to implement the transformation and become aware of the need for this transformation. Thus, the family and the school are two institutions with the utmost importance for this awareness of the real objective of the educational technological space.

\section{School}

In the school environment in which teaching-learning is involved, teacher education is most often considered as the main factor for the success and failure of the learner. We know that this teacher education consists of stages that involve a long and flawed process, as the teacher seeks a preparation that at the end of the course guarantees him a diploma, but it is necessary to take into account that the diploma by itself does not guarantee the success in your professional life. It should be understood that training is the result of continuous learning and the development of some conditions, one of which Antunes (2009, p.190) presents us with, saying that "Competence corresponds to the ability of subjects to connect the "knowledges" they have acquired throughout from life to situations of experience, in order to, by resorting to this knowledge. Silva ${ }^{9}$ tells us about a study by Paulo Micelli, which presents a typology of current education professionals, revealing the different types of commitment and performance that surround Brazilian schools, such as: 
A passing teacher - is one who is always focused on the achievements of the future and never on the challenges and contradictions of the present.

I. Leaving or End of Career Teacher-They are the accommodated ones who no longer have any desire.

II. Handicapped teacher - is one who does not change professions because of absolute impossibility or incompetence. He wasted too much time with teaching and his repentance came a little late, especially with regard to remuneration.

III. Bad professional teacher - he is the frustrated one who has not been successful in other areas of the labor market and, therefore, dedicates himself, by force, to teaching.

IV. Teachers don't live off of this - What makes teaching work a mere job and prides themselves on the condition of not being concretely involved in the causes and needs of school education.

V. Conscious and idealistic teacher - he is the teacher in the real sense of the term in which the difficulties of survival and various oppressions pass, he still resists and fights for dignity within the scope of his work

Based on this study, we can infer that despite this typology having been analyzed two decades ago, it remains current as there is a differentiated commitment between professionals with equal teaching performance. These distinctions can be interpreted as a factor of identity formation related to the individual, intellectual formation that this "teacher" subject went through for the exercise of his professional formation. As stated by Garrido. ${ }^{10}$

The classroom can also be a training space for the teacher. Initial training cannot account for the variety and complexity of situations that the future teacher will face. Nor will he be mature enough to assimilate all the challenges that pedagogical practice poses. The school environment involves teaching-learning and teacher training is considered the main factor for the student's success or failure, but we know that it is constituted by stages that are susceptible to failure, and it is necessary to take into account that the diploma by itself does not guarantee the success since theory is associated with practice, which demands monitoring and conditions conducive to development.

In the training path, the teacher develops skills and competences that, added to their life experiences, will help them to understand and better deal with the challenges posed by professional life. the multiple situations found, making use of elements formed by intuition, methods, techniques, experiences, information, principles, concepts, associated with knowledge accumulated throughout life, since all competence is exercised and is revealed in the confrontation. In this sense, the competent teacher who develops the role of mediator in the classroom in the education of the reader is one who is able to deal with people with ease, as we are different from one another. Knowing how to listen and having reflective listening, because the teacher's voice in the classroom should not be the last nor considered the only truth.

\section{Thus Moran ${ }^{11}$ states that:}

Changes in education also depend on having more open administrators, directors and coordinators, who understand all the dimensions that are involved in the pedagogical process, in addition to the business related to profit; that support innovative professors, that balance business, technological and human management, contributing to an environment of greater innovation, exchange and communication.
In this context, it is necessary to have a passion for teaching and always present yourself as a model, as being a teacher involves responsibility and commitment because whoever embraces this profession cannot be a teacher for a temporary issue and/for a budget supplement, but as something pleasurable to be do, because you are a teacher for a lifetime. The classroom, which should be a space for reinvigorating strength and developing competences and skills, enabling and encouraging students to take part in book culture, has become a place of distancing.

\section{Technological mediation: school space}

Technological mediation in the school space is understood as the act of making the place suitable, arousing interest and engagement in the target audience, so Petit ${ }^{12}$ believes that "The mediator's action therefore goes far beyond activities of reading that has a purely objective content. Most of the time, educators - reading mediators create lasting bonds with users of reading spaces", that is, it is a situation beyond the learned theory, as educational technological mediation activities consist of an act of developing innovative activities, allied technology, in a free and pleasurable way, which does not require great artistic skills from the mediator, but rather innovative ones. What is important is that this mediator demonstrates a real enthusiasm for this activity, sharing and exchanging experiences with students. This mediation action can be practiced in several places, but government support is essential as new initiatives expand the existing range, generating benefits for Brazilian society. Therefore, the emphasis on the qualification and improvement of this professional when using and disseminating these tools in the school context.

\section{School challenges in times of pandemics}

The Covid-19 pandemic created new and complex challenges for the entire world population, and social distancing was necessary to minimize the effects, but the consequences will still take some time to be resolved. It is estimated that $91 \%$ of all students worldwide and over $95 \%$ in Latin America are temporarily out of school due to the consequences of Covid-19. Public or private, schools were closed to contain the spread of the virus, so it was necessary to quickly adopt new ways to maintain the educational process. Brazil followed the global trend and state education networks have advanced in school innovation with distance and remote learning through the availability of online platforms, teaching classes and sending digital materials on social networks and apps. The social disparity between public and private education systems in basic education was even more notorious. The lack of governmental planning and organization has increasingly undermined Brazilian education, making it impossible to explain whether the objective is to educate and it is continually failing or hindering access to education, which is happening with excellence.

Learning takes place in any space, as long as there is mediation and exchange of experiences, so that meaningful learning will take place. Spaces and environments are part of a complex process, and need to be addressed to enable the development of students, in addition to improving teacher training.

\section{Final considerations}

Technology and media resources are great allies in the teaching/ learning process, which are considered important for any and every citizen. The educational space goes beyond deciphering symbols and places, and the educational environment must take place in a way that awakens interest and pleasure. It is up to the mediators to know the stages of development of students in order to provide diversified 
and innovative activities, in order to improve and contribute to their educational technology training. Thus, technology must be used as an auxiliary resource in the construction of learning, a process that needs to be awakened in the child with pleasure, that is, with meaning for life, for the world. We realized that continuing teacher education favors resinifying the pedagogical practice, in the sense of bringing it closer and closer to the students' social context. Given the above, we hope that this work can contribute to the reflection of everyone involved in the process of understanding how to use technological tools as an auxiliary tool in the teaching-learning of students. Therefore, this research does not end here, leaving open possibilities for further studies on this topic.

Regarding the social isolation of the pandemic period, we reaffirm that the suspension of in-person classes would not generate so many impacts if the use of other environments, guaranteeing the maximum possible socialization, were already a culture of improvement in the educational system. In the uncertainty of favorable conditions for a safe face-to-face return, the State Education Councils guide educational institutions to take advantage of educational technology tools on a large scale, such as virtual teaching platforms and environments, to guarantee the pedagogical processes of learning. Thus, taking forward distance education solutions becomes complicated, especially for the most vulnerable social groups, who lack computers in their homes, access to the internet network and other technological tools for accessing online networks. Therefore, with the restrictions to prevent the spread of the virus, education also needs a lot of attention in order to overcome physical distance and create new paths for the teachinglearning process, covering all student audiences. Quality education is everyone's right, so each and every strategy must be used to guarantee it.

\section{Acknowledgments}

None.

\section{References}

1. Brazil. Ministry of Education. Secretariat of Basic Education. Theories of educational space. Brasília: University of Brasília, 2008. p. 106.

2. Lévy P. Cyberculture. São Paulo, SP: Ed. 34, 1999.

3. Schnitman, Ivana Maria. Experience report: pedagogical mediation and the success of an online educational experience. ETD - Educ. Have. Dig., Campinas, v.12, n.esp.,2002. p. 287-314.

4. Ramal AC. Distance education: between myths and challenges. Patio Magazine, year 5, n. 18, Aug./Oct., 2001. p. 12-16.

5. Almeida CC. New Technologies and Interactivity: beyond mediated interactions. DataGramaZero. Journal of Information Science. 2003;4(4).

6. Faria ET. Face-to-face and virtual education: essential complementary spaces in schools and companies. Porto Alegre - RS: EDIPUCRS, 2006.

7. Freyberger, Adriana. The construction of the educational environment: a collaborative action research in a Child Education Center. $192 f$. Thesis (Doctorate in Education) - Faculty of Education, University of São Paulo, São Paulo, 2005.

8. Fornero, Lina Iglesias. The Organization of Spaces in Early Childhood Education. In: Zabalza, et al., editors. Quality in Early Childhood Education. Porto Alegre: Artmed, 1998. p. 229-281.

9. Silva, Ezequiel Theodoro da. Reading at school and in the library. Campinas: Papirus, 1985.

10. Garrido, Elza. Analyzing teacher-student verbal interaction according to categories based on the conceptual change model. In: Brzenski, editor. Teacher training a challenge. Goiânia: editor of the Catholic University, Goiás, 1996.

11. Moran JM. Innovative teaching and learning with audiovisual and telematic technologies. In: Moran JM, et al., editors. New technologies and pedagogical mediation. 14. ed. Campinas: Papirus, 2000.

12. Petit, Michel. Young people and reading: a new perspective. São Paulo: 34, 2009. 